\title{
Bioindication of aquatic habitats with diatom algae in the Pamir Mountains, Tajikistan
}

\begin{abstract}
Paper represents the first results of bioindication analysis of water quality in the Pamir aquatic habitats including rivers, lakes, mineral and hot springs with help of diatom algae. Altogether 438 bioindicators taxa were revealed from 558 known diatom algae in Pamir. Twelve environmental properties were assessed with help of species autecology. Bioindication analysis was doing for environmental parameters of water temperature, $\mathrm{pH}$, salinity, and oxygen saturation as well as was assessed substrate preferences and nutrition type of diatoms, trophic state of water bodies and water quality on the base of organic pollution indications. We was find that diatoms in Pamir are strongly autotrophes, benthic or plankto-benthic inhabitants that preferred lowsaline, low-alkaline, middle oxygenated clear fresh water with low organical pollution and oligo-to meso-eutrophic state. Compative floristics of Pamir and surrounding diatom floras let us to assume that studied algal flora can represent regional reference area for close related high mountains habitats.
\end{abstract}

Keywords: diatoms, algal flora, bioindication, pamir, tajikistan
Volume 3 Issue 3 - 2018

\author{
Niyatbekov T,' Barinova SS² \\ 'Department of Botany, Plant Physiology and Genetics, Republic \\ of Tajikistan, Tajikistan \\ ${ }^{2}$ Department of Botany, University of Peshawar, Pakistan \\ Institute of Evolution, University of Haifa, Israel
}

Correspondence: Barinova SS, Institute of Evolution, University of Haifa, Mount Carmel, 199 Abba Khoushi Ave, Haifa, 3498838, Israel, Email sophia@evo.haifa.ac.il

Received: February 01, 2018 | Published: May 02, 2018

\section{Introduction}

The ecological assessments of environmental variables ranges that can characterize inhabited water body, river basin or even region are progressive and economic methods that implemented for many countries in monitoring, and one of them is algal bioindication. ${ }^{1}$ Diversity of algae in Tajikistan has been studied sporadically during the last century. The uppermost part of Tajikistan territory is Pamir where the large regional rivers Panj and Gunt are started. The rivers and streams in Pamir are placed in high mountains and started from glaciers. The altitude gradient of the Pamir aquatic habitats is represent of about two thousand meters and ranged between 2,000 and 4,000 $\mathrm{m}$ above the sea level (a.s.1.). This high mountain area is very rich in thermal and mineral waters, which in a way are unique habitats characterized by a constantly as well as high temperature from $10{ }^{\circ} \mathrm{C}$ to $86{ }^{\circ} \mathrm{C}$, various chemical compositions and saturation by carbon dioxide, nitrogen gase and hydrogen sulphide. It classify as hydrogen sulfide-siliceous, hydrocarbonate-sulphate-calciummagnesium, chloride-sulfate-calcium-sodium, hydrocarbonatesulfate-sodium and weak radon-chloride-sulfate. ${ }^{2,3}$ In these waters, for many centuries, a special community of algae with a specific species composition and degree of species resistance to peculiarly extreme environmental conditions was formed and developed. Rivers and lakes are numerous in Pamir in altitude gradient. Therefore, Pamir is one of high altitude area in Eurasia with close relations to Hindu Kush, Altay, and Himalayas. Its territory have diverse aquatic habitats from clear freshwater large rivers, streams, lakes, to mineral and thermal springs which are occupied by diverse algal communities. Freshwater algae are widely used in ecological assessment of water quality. ${ }^{1}$ It is very important to know about algal diversity in inland waters because most of algal species can be used as environmental indicators. Usually, diatom algae represent about one-half of species richness in the well-studied middle-latitudinal regional algal floras. ${ }^{4}$ The references literature data on Pamir regional algal flora is known before our study from sporadically collected material in period 1930-
$1983 .{ }^{5-9}$ The regular work has been in 2000-2006 by G.R. Jumaeva. ${ }^{10}$ Our own study of diatoms in thermal and mineral springs is enriched the regional diversity by 134 diatom species (166 with infraspecific taxa).$^{11}$ We assume that the diversity of this group of algae in Pamir is still far from complete. Altogether 558 taxa of diatom algae are known in Pamir aquatic habitats as a result of references collecting data and our own research. ${ }^{12}$ So, the list of species and studied waterbodies are representative for ecological characteristic of this highmountain territory. Thus, the aim of our work was to reveal bioindicator species in the full taxa list of diatom algae from different habitats of Pamir and to characterize of water quality on the base of species autecology by bioindication methods.

\section{Materials and methods}

\section{Sampling and laboratory studies}

Our own material for this analysis is comes from 150 samples collected during few field trips in summer period of 2000-2015 from various thermal and mineral springs located at an altitude from 2,360 $\mathrm{m}$ to $3,800 \mathrm{~m}$ above the sea level. ${ }^{11}$ Algological samples were collected by scratching and scooping, placed in $15 \mathrm{ml}$ plastic tubes, and partly fixed with 3\% neutral formaldehyde solution, as well as partly not fixed and transported to the laboratory in the ice box. The diatoms shells were prepared by the peroxide technique ${ }^{9}$ modified for glass slides ${ }^{10}$ and were placed in the Naphrax ${ }^{\circledR}$ resin in two repetitions from each sample. The structure elements of the diatom shells were observed with Nikon stereomicroscope under magnifications $740 x-1850 x$ from two repetitions of each sample and were photographed with a DC in the Institute of Botany, Plant Physiology and Genetics, Dushanbe, Republic of Tajikistan, and the Institute of Evolution, University of Haifa. Diatom species were defined from permanent glass slides with help of international handbooks and its scientific names were validated with help of algaebase.org. Autecology of diatom taxa was taken from our database. ${ }^{13}$ 


\section{Taxonomic data compilation}

Total species list of the Pamir diatom flora was compiled in first time $^{12}$ from our study of the mineral and thermal springs as well as from referenced lists in publications about diatom diversity in Pamir aquatic habitats. ${ }^{2,3,5-11}$ All collected taxonomic data was adapted to the modern taxonomic system with help of algaebase.org. Taxonomic list was analyzed in the Microsoft Access 2013 Program.

\section{Results and discussion}

\section{Diversity of diatom algae in pamir habitats}

Altogether 558 taxa of species and subspecies levels has been revealed form the references data and our own study in Pamir. ${ }^{12} \mathrm{We}$ studied earlier the influence of habitats altitude on species richness of freshwater algae and find that diversity is increased with increasing altitude $^{14}$ up to two thousand meters a.s.l. Our list of diatom species in Pamir is comparable with richness of diatoms in close placed and well studied mountain regional floras such as South-Tajik Depression or Caucasus, ${ }^{15-17}$ but in the regions where algal diversity study are in initial stage like Kabul River basin in Pakistan ${ }^{18,19}$ the Pamir diversity of diatoms looks like much richer. Bioindication properties were found for 438 taxa of diatoms from Pamir aquatic habitats. The list of bioindicators contains about $78.4 \%$ of total species list of Pamir diatoms (Table 1). Therefore, the bioindicational analysis can be satisfy representative.

\section{Bioindicational analysis of the Pamir environment based on diatom algae autecology}

Bioindicators of Pamir environment were revealed for ten ecological variables: substrate preferences, water oxygen saturation, water $\mathrm{pH}$, salinity, organic pollution related to self-purification zones and Indices of saprobity, trophic level of ecosystem habitat, and type of nutrition of diatom cells (Table 1). Can be seen, that substrate preferences are the property of species, which mostly represented in the Pamir diatom flora (428). Salinity preferences are known for 411 taxa, and water $\mathrm{pH}$ for 390 . Organic pollution indicators are represented by more than 300 taxa. Important for aquatic inhabitants' property, the water oxygen saturation can be accessed on the base of 261 indicator taxa. Less known property of diatoms is the water temperature preferences. Nevertheless, the temperature preference is known for 89 diatoms species in Pamir. We were constructed the distribution of indicator taxons of each of the environmental indicators over trend of amplifying the value of the indicator group for the revealing prevailed groups of indicators. Standard deviation line was added to each distribution for cut off the dominant groups. The trend line also was constructed to show each variables tendency in Pamir. The distributions were constructed for indicator groups as the environmental property increases. So, three ecological groups were found in 428 substrate preferences indicators in the Pamir diatom flora (Figure 1). Trend line of distribution show sharp increasing of benthic group in species number. The STDEV line, also added to most ecologically important groups the planktonic-benthic group of species that preferred slowly streaming waters. Temperature preferences indicators are divided into four ecological groups for Pamir. Can be seen (Figure 1) that temperate water temperature species are prevail, but important also that cool-water species and warm-water indicators are visible in distribution but cannot be included in the dominant groups as shows the STDEV line.

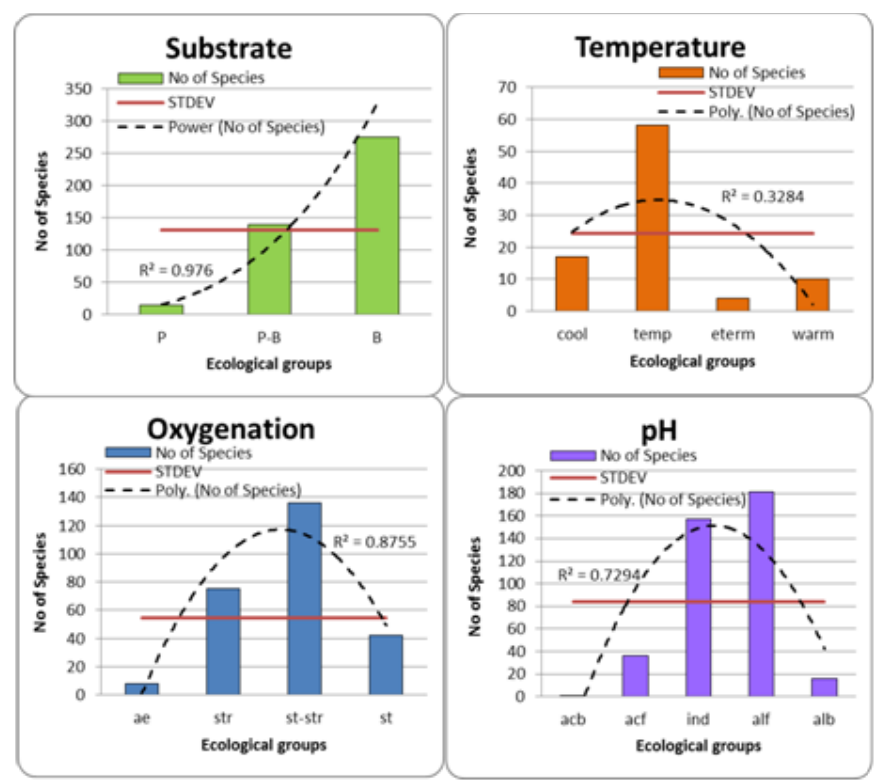

Figure I Distribution of species indicators of the diatom Pamir algal flora over the ecological groups of substrate preferences, temperature, oxygen saturation, and water $\mathrm{pH}$. The ecological categories abbreviations as in Table 1.

Indicators of water oxygen saturation reflect the predominance of slowly streaming waters group (Figure 1), but species preferring streaming waters also were numerous and over the STDEV line. Water $\mathrm{pH}$ indicators were represented by six ecological groups with prevailing of indifferent and alkaliphilic species as can be seen with trend and STDEV lines (Figure 1). Water salinity indication reflect fresh and low-saline waters in Pamir (Figure 2) as is shown by trend and STDEV lines, although the wide amplitude of indicators is presented from halophobes to mesohalobes. Organic pollution indication by diatom species according T. Watanabe (Figure 2) show prevailence of middle-polluted waters group with the trend line, but with STDEV line can be seen in dominant groups the saproxenes also, that are indicators of fresh clear natural waters. Seven groups of trophic state indicators were revealed in Pamir diatom flora (Figure 2) in which tendency to oligotrophic groups can be seen with trend line. Nevertheless, STDEV line shows two different groups of trophic indicators related to not only oligotrophic waters (on left in Figure 2) but also to mesotrophic and eutrophic waters (on right in Figure 2 ). Therefore, the indicators distribution reflects the different trophic state of the Pamir water bodies from oligotrophic to eutrophic. The distribution of Pamir diatom indicators over the nutrition types properties of organisms show strongly prevailing of autotrophs that preferred photosynthetic way of nutrition in the ecosystems (Figure 2). Assessment of organic pollution was doing with help of grouping of saprobity indicators to major Water Quality Classes based on the species-specific saprobity according Sládeček. Figure 2 show that diatoms in Pamir are divided into four water quality Classes that reflects the waters from natural clear to significantly polluted. The colors in the Class of Water Quality histogram are as in EU color code. This distribution shows Classes 2 and 3 prevailing with both, trend and STDEV lines. Pamir environment bioindicational analysis show similar results with other high mountain regions such as Caucasus ${ }^{16}$ where mountain part of territory has minimal anthropogenic influence. In contrary, even in close related South-Tadjik Depression algal flora ${ }^{15}$ we can see of anthropogenic influence doing mostly from 
agriculture. In such low studied regions with high agricultural and other human activity, as the Kabul River valley with tributaries from Hindu Kush to Peshawar, ${ }^{18,19}$ can be seen decreasing of algal species richness with increasing of water pollution by salinity and organic matters. Therefore, the Pamir diatom algal flora can represent the regional background diversity for comparing of closely spaced high mountain habitats.



Figure 2 Distribution of species indicators of the diatom Pamir flora over the ecological groups of salinity, organic pollution according Watanabe, trophic state, nutrition type, and water quality Class based on the species-specific saprobity according Sládeček. The colors in the Class of Water Quality histogram are in EU color code. The ecological categories abbreviations as in Table 1.

\section{Conclusion}

Altogether 558 diatom taxa were revealed for total list of diatom algae in Pamir habitats, ${ }^{12}$ and 438 of them were bioindicators. Twelve environmental properties were assessed with help of species autecology. Bioindication analysis revealed prevalence of species preferring benthic or periphytonic lifestyle (433 indicators), temperate water temperature with significant number of cool-water and warmwater indicators (92 taxa). Pamir diatoms were mostly represented by slow streaming groups but streaming water indicators were also numerous (266 indicators). Water-pH indicators were mostly represented by $\mathrm{pH}$-indifferent group and alkaliphilic species that let us to characterize the Pamir water as low-alkaline (395 indicators). The water salinity as one of important variable for aquatic diversity was indicate the waters in Pamir as fresh and low-saline (416 indicators). The sunlight energy utilization property for diatoms is strongly prevail as show indication of photosynthetic way in nutrition for organisms in aquatic ecosystems of Pamir (208 indicators). The indication of Pamir water bodies trophic state show two different groups of species reflect of oligotrophic and meso-eutrophic properties of studied water bodies (324 indicators). Organic pollution indication according $\mathrm{T}$.
Watanabe reflects low-polluted waters in Pamir that usually represent of fresh clear natural waters (246 indicators). The same variable in the Sládeček system with 388 indicator taxa help us to characterize Pamir waters as natural clear or slightly organically polluted, with water quality Class 2 and 3. As results, bioindication of Pamir waters by diatoms show natural slowly streaming low alkaline and low saline fresh waters with low level of organic pollution inhabited with species that preferred photosynthesis for proteins creation. Thereby, bioindication revealed the numerous species that are unique in Pamir diatom flora, about $22 \%$, which have not now any information yet about its ecological properties. The important property of revealed diatom flora can be not only large species richness but also wide amplitude of the environmental variables in water temperature, oxygen saturation, salinity, and trophic state of water bodies which they inhabited. Therefore, this first experience of bioindication implementation to Pamir environment assessment demonstrated not only importance of ecological approach to environmental properties analysis in hard-to-reach high mountain habitats but also large perspectives of the method for the system of nature protection in the face of anthropogenic pollution press and climate change.

\section{Acknowledgements}

The work was partly supported by the Israeli Ministry of Aliyah and Integration.

\section{Conflict of interest}

Author declares there is no conflict of interest.

\section{References}

1. Stevenson J. Ecological assessments with algae: a review and synthesis. $J$ Phycol 2014;50(3):437-461.

2. Bokhodjaev I Ya, Davlatmamadov Sh M. Medical mineral springs of Pamir. Tajikistan, Dushanbe. 1994.

3. Churshina NM. Mineral, thermal and cold water. In: Tajikistan (nature and natural resources). Dushanbe:1982;125-131.

4. Barinova S. Algal diversity dynamics, ecological assessment, and monitoring in the river ecosystems of the eastern Mediterranean. New York, USA: Nova Science Publishers; 2011.

5. Petersen JB. Algae from O Olufsen's second Danish Pamir Expedition 1898-1899. Dansk Bot Ark 1930;59(1):1-60.

6. Balashova NB, Nikitina VN. To the algal flora of some thermal springs of Pamir. Proceedings of VI conference of lower plants of Middle Asia and Kazakhstan. Dushanbe, 1978;(22).

7. Muzafarov AM. Algal flora of the Central Asian water bodies. Tashkent: Uzbekistan Academy of Science Publisher; 1965.

8. Ergashev AE. Materials to the algal floras of natural and artificial, thermal and hot springs of Middle Asia. In: Lower Plants of Middle Asia. Tashkent, Fan. 1969;3-37.

9. Baturina LR. Algae of thermal springs of Tajikistan. PhD Thesis, Tajikistan, Dushanbe. 1983.

10. Jumaeva GR. Algal flora of major thermal and mineral springs of Pamir. $\mathrm{PhD}$ Thesis, Tajikistan, Dushanbe. 2008.

11. Barinova S, Niyatbekov TP. Algal diversity of the Pamir high mountain mineral springs in environmental variables gradient. Int. J. Envir. Sci. Nat Res. 2017;14(3):555706. 
12. Barinova S, Niyatbekov TP. Diatom species richness in algal flora of Pamir, Tajikistan. European Scientific Journal. 2018;14(3):301-323.

13. Barinova SS, Medvedeva LA, Anissimova OV. Diversity of algal indicators in environmental assessment. USA. Tel Aviv: Pilies Studio; 2006.

14. Barinova $\mathrm{S}$. The effect of altitude on distribution of freshwater algae in continental Israel. Current Topics Plant Biol. 2011;12:89-95.

15. Barinova S, Boboev M, Hisoriev H. Freshwater algal diversity of the South-Tajik Depression in a high mountainous extreme environment. Turk J Bot 2015;39(Suppl 1-22):535-546.

16. Barinova SS, Kukhaleishvili L, Nevo E, et al. Diversity and ecology of algae in the Algeti National Park as a part of the Georgian system of protected areas. Turk J Bot 2011;35:729-774.
17. Barinova S, Kukhaleishvili L. Diversity and ecology of algae and cyanobacteria in the Aragvi River, Georgia. The Journal of Biodiversity. Photo. 2014;113:305-338.

18. Barinova S, Khuram I, Asadullah Ahmad N, et al. How water quality in the Kabul River, Pakistan, can be determined with algal bio-indication. Adv Stud Biol 2016;8(4):151-171.

19. Khuram I, Barinova S, Ahmad N, et al. Ecological assessment of water quality in the Kabul River, Pakistan, using statistical methods. Oceanol Hydrobiol Stud. (017;46(2): 140-153. 